\title{
Jordan Myerst \\ KANTIANS MAKE BAD FRIENDS; SUSPENDING MORAL RESPONSIBILITY IN RELATIONSHIPS
}

Abstract. In this essay, I will briefly examine the Kantian ethical tradition as inherited by Christine Korsgaard. I argue that the Kantian is committed to a morally impractical conclusion: that she must hold others morally responsible without exception. I explain the concept of moral responsibility in the Kantian and consequentialist frameworks, and then illustrate why the Kantian's is an impractical imperative through an examination of its interpersonal effects. I end by suggesting that a consequentialist view offers a more robust framework for moral responsibility.

Keywords: moral responsibility, Korsgaard, Kant, relationships, consequentialism, blame, praise, attitudes.

Для цитировАния: Myers J. Kantians Make Bad Friends; Suspending Moral Responsibility in Relationships // Логико-философские штудии. 2021. T. 19, № 2. С. 123 126. DOI: 10.52119/LPHS. 2021. 94.87 .010 .

Being a Kantian is difficult for a multitude of reasons, but one in particular is the standard to which you must treat the people in your life. In this essay, I will briefly examine the Kantian ethical tradition as inherited by Christine Korsgaard and argue that it commits her to a morally impractical conclusion - namely, that the Kantian must be committed to holding people morally responsible without exception. I will then illustrate why this is an impractical imperative by examining its interpersonal effects and suggest that a consequentialist view offers a more robust framework for moral responsibility.

Christine Korsgaard is perhaps the most renowned philosopher within the Kantian tradition today - and for good reason. In her work, she introduces an interpretation of the second formulation of Kant's Categorical Imperative that is uniquely incisive. The second formulation states that one must treat humanity (or every individual) as an end in and of herself, never as a means to an end (Kant, Gregor 1785/1998: 4:429). As a Kantian philosopher, Korsgaard accepts this imperative - and I will not be questioning her overall acceptance of the Kantian moral view. Instead, I want to explore what this imperative logically commits her to. Korsgaard insightfully extrapolates "treating someone as an end" to treating her under the guise of being morally responsible, and in this way, to respect their autonomy as an individual (Korsgaard 1992: 305-306, 311$312,317-319)$. I do not find fault with her interpretation - it is reasonable to assume

\footnotetext{
${ }^{1}$ Jordan Myers, University of Pittsburgh. Jom133@pitt.edu
} 
that treating someone with respect is to treat her as if she is fully autonomous. The next reasonable move is to assume that autonomy should be the sufficient condition for moral responsibility.

It is the way in which Korsgaard accepts this imperative, though, that ties her to a difficult conclusion. She accepts that holding individuals morally responsible follows from the second formulation of the categorical imperative - an imperative that does not permit of exceptions. The imperative is to "always and at the same time" hold people responsible, so if one wishes to forgo this moral commandment, it cannot be done from within a Kantian framework - it must come from outside the moral theory.

In order to examine what is so impractical about this conviction, it is first useful to understand what "holding people morally responsible" entails. There are several philosophical (and informal) notions of moral responsibility. On a consequentialist account, to hold someone morally responsible would only be morally correct if it engendered some positive benefits in them-i.e., to make one a better person, create closure for the wronged party, or deter others from committing the same wrongful act (Dennett, Caruso 2021: 6-7, 11). This is not the account Korsgaard wants to accept. Instead, Korsgaard takes a largely attitudinal view of moral responsibility, saying that to hold someone responsible is to react to her as we would an agent: to blame, praise, desire vengeance for a wrongdoing, reciprocate good will, etc. It is, in large part, to treat someone as they deserve to be treated, in a very common-sense understanding of the term (Dennett, Caruso 2021: 11). It is not clear from her cited work if Korsgaard has committed herself to a view on what is called desert-based moral responsibility, wherein blame, or specifically punishment, is deserved in a deeper sense than being justified by good consequences (Pereboom 2014: 2, in Dennett, Caruso 2021). Her work speaks more about attitudes in interpersonal relationships than about actions, specifically punishment. 2 This narrows the focus to strictly attitudes that constitute moral responsibility, expressed in interpersonal relationships.

Why is Korsgaard's commitment an impractical one? The imperative to always treat others as agentic appears innocuous, but I argue, only spuriously so. I believe that the Kantian view of responsibility does not permit for the necessary, occasional suspension of moral responsibility in relationships. The ironic aspect of this argument is that Korsgaard herself explicitly states that these attitudes are themselves required for interpersonal life (Korsgaard 1992: 305-306, 311-312). For her, interpersonal life itself is only made possible through the application of these attitudes - and I have no quarrels with that claim, but I argue that her entailment to apply these attitudes without exception is problematic for the very relationships she hopes to maintain. My brief rebuttal is to suggest that fully adhering to what we might call Korsgaard's Categorical Imperative vitiates the very interpersonal relationships she hopes to respect, thus

\footnotetext{
${ }^{2}$ Korsgaard does go on to provide examples of where we might suspend moral responsibility, but I argue this is inconsistent with her acceptance of the Categorical Imperative. Recall that I am exploring what a Kantian tradition logically commits oneself to, and why this is unreasonable.
} 
making her project self-defeating. Her theoretical moral grounds demand a practice which, if carried out, would destroy the relationships it hoped to maintain. But I have yet to demonstrate why I think this is true, and why another moral framework is more pragmatic.

First, I will present two everyday examples in which adhering to the strict imperative to always hold responsible creates interpersonal strife. These are examples where I suggest the cost of indulging Kantian attitudes could be reasonably morally outweighed by the benefits of their suspension in favor of consequentialist goods. But because the Kantian does not have theoretical grounds for exempting such cases, I intimate that a consequentialist view is more fitting, or at the very least, gives one more options without betraying one's moral principles.

Imagine you are at a family dinner for the holidays. Imagine you happen to be an American family, and perhaps your uncle believes that Donald Trump did win the November election, or that COVID vaccines have tracking devices in them. You are confronted with a choice; you can respond to him as fully morally responsible, confronting him about these questionable beliefs. Or, you can dispassionately assess your situation-you will likely not persuade your uncle to change his mind and attempting to do so will only ruin the dinner. Are you really going to stain the one time per year you visit extended family?

You could also imagine that your sister has been absent in sharing her duties caring for your sick mother. She lives an equal distance to your mother's home, but has been simply refusing to share the burden of taking care of her in her old age. You are understandably angered by this capricious laziness, but the desire for deserved retribution will only worsen the situation, putting your mother in an even more precarious situation.

The problem with a Kantian commitment to the constant application of attitudinal moral responsibility is that cases like these highlight the impracticality, and perhaps impossibility, of such a commitment. If, however, one does suspend moral responsibility and treat the person in question as an object to be accounted for, something in the situation to be dealt with, one does this in spite of their moral duty. Thus, the Kantian is forced to undertake an impossible standard or endorse the desultory suspension of one's moral principles.

If, however, one views these scenarios through a consequentialist framework, there are more doors open to her. The consequentialist can weigh the costs and benefits of the above scenarios, whereas the Kantian only has her imperative to react to people as autonomous agents who deserve their just deserts.

The consequentialist can ask if arguing over politics at the Christmas family dinner is really the wisest (or best consequences-producing) course of action. Perhaps merely biting your tongue will be better for everyone involved, and to make this easier, you might suspend all moral blame entirely, viewing your uncle as a component of the dinner that you find challenging. In this way, he becomes an obstacle to a civil family dinner- 
something to be worked around, like a shortage of forks or sitting in uncomfortable chairs.

The consequentialist can also take a removed approach towards her sister - even though she might deserve blame and even retribution, you may treat her as something to be accounted for or dealt with for your mother's sake. You can simply remove your sister from the situation without anger, malice, or blame in order to better your mother's conditions of care.

This is not to say that the consequentialist must always suspend moral responsibility, but it is a live option for her-without any inconsistencies with her larger moral theory. The attitudes comprising moral responsibility are, as Korsgaard indicated, generally essential for maintaining relationships. However, I hope to have illustrated why the logical entailment to constantly hold to these attitudes would be damaging to any relationship. And, it is you as well who must sometimes be the recipient of these suspensions of interpersonal attitudes - sometimes you are the unreachable malcontent, the unhinged partisan, or the indolent child. The suspension of moral responsibility is a crucial and necessary part of nearly any relationship, at least from time to time. It serves as a lubricant, allowing each party to exist more freely and deal with issues caused by the other. In this way, a suspension of responsibility can be the very thing that allows a relationship to stay intact with the future possibility for many more legitimate applications of moral attitudes.

In this essay, I hope to have illuminated a standard to which no Kantian could comply, and to have shown that this is not an issue with the moral agent, but rather with the moral theory. There are cases in interpersonal life that simply require the suspension of moral attitudes, and a consequentialist framework can provide this scaffolding without need for an inconsistency in its application.

\section{References}

Dennett, Caruso 2021 - Dennett D., Caruso G. Just Deserts. Medford, USA: Polity Press, 2021.

Kant, Gregor 1785/1998 - Kant I., Gregor M. J. Groundwork of the Metaphysics of Morals. Cambridge, UK: Cambridge University Press, 1785/1998. [Cited in text as "G, 4:xxx".]

Korsgaard 1992 - Korsgaard C. M. Creating the Kingdom of Ends: Reciprocity and Responsibility in Personal Relations // Philosophical Perspectives. 1992. Vol. 6. P. 305-332.

Pereboom 2014 - Pereboom D. Free Will, Agency, and Meaning in Life. New York: Oxford University Press, 2014. 